\title{
Fair Value Accounting and the Cost of Equity Capital: The Moderating Effect of Risk Disclosure
}

\author{
Ashwag Dignah ${ }^{1}$, Radziah Abdul Latiff ${ }^{1, *}$ Zulkefly Abdul Karim ${ }^{2}$, and Aisyah Abdul Rahman ${ }^{3}$ \\ ${ }^{1}$ School of Accounting, Faculty of Economics and Management, Universiti Kebangsaan Malaysia, Malaysia \\ ${ }^{2}$ School of Economics, Faculty of Economics and Management, Universiti Kebangsaan Malaysia, Malaysia \\ ${ }^{3}$ School of Management, Faculty of Economics and Management, Universiti Kebangsaan Malaysia, Malaysia
}

\begin{abstract}
Evidence thus far suggests fair value accounting poses risk and affects firms' returns in some ways. This research, on a sample of Asian banks, improves the understanding of the information risk effect of fair value accounting by examining the moderating role of risk disclosure in the relationship between fair value accounting and the cost of equity capital. The results from a generalised method of moments on dynamic panel data analysis, show that risk disclosure mitigates the asymmetric information problem. Thus the findings contribute towards the standard setters' effort in improving the practice of fair value accounting, and suggest that there are benefits in mandating disclosure especially for banks.
\end{abstract}

\section{Introduction}

The cost of equity capital (COE) is one of the main concerns of firms (1). Information asymmetry and risk could increase the COE, the cost of raising funds, as suppliers of capital reduce the stock price. In this regard, fair value (FV) accounting is an effort to provide relevant information to investors for decision making and reduce their risk of making wrong decisions based on outdated information, such as that based on historical cost. However, Barth (2), Lins et al. (3) and Christensen and Nikolaev (4), among others, criticized FV measurement for introducing more volatility and generating the information asymmetry problem and risk.

Past research finds proportion of fair valued assets (FVA) is positively related to the COE. It is a conjecture at this point that the effect of FVA on the COE could be moderated by practising risk disclosure. Risk disclosure will offer the stockholders justification about the risk and provide them with more relevant information; this action reduces the information asymmetry and the risk as reported by Amran et al. (5). Linsley and Shrives [(6),(7)], Aljifri \& Hussainey (8), Abraham and Cox (9) discuss the importance of disclosing information on risk when the level of risk is expected to be high, such as when FV accounting is adopted. Botosan (10) examine the influence of disclosure on the COE. Consequently, practising risk disclosure is expected to reduce the effect of asymmetric information and information risk with FV accounting on the COE. However previous studies report that as the level of risk increases risk disclosure decreases because bank managers are less likely to disclose information about risk that shows a weakness [(11);(12); (13)]. Bank managers prefer to reveal a favourable situation that shows their ability to users and helps them to differentiate their bank from other banks.

Thus, according to the previous discussion, a considerable debate has arisen between academic papers regarding the direction of the influence of risk disclosure in the relationship between FVA and the COE. These conflicts between academic researchers make the impact and benefit from risk disclosure unclear. Thus it is important to examine whether risk disclosure moderates the relationship between FVA and the COE, which is the objective of this paper.

Risk disclosure is expected to play a role differently for different types of FVA, quoted and unquoted FVA. The demand for risk disclosure increases differently with different types of FVA, because each type has different kinds and degrees of risk. Consequently, these different levels of FVA emphasize the importance of investigating whether risk disclosure moderates the relationship between different levels of FVA (quoted and unquoted FVA) and the COE.

Furthermore, the intention of previous studies and regulators to decrease the $\mathrm{COE}$ by practising disclosure is the primary motivation for this study. Diamond and Verrecchia (14), Clarkson et al. (15), Botosan (10), Richardson and Welker (16), Botosan and Plumlee (17), Hail (18), Chen et al. (19), Cheng et al. (20), Francis et al. (21), Armitage and Marston (22), Zhaohui (23); Lopes and De Alencar (24), Lopez (25) and Shehata et al. (26) are the previous researchers who focused on the effect on the $\mathrm{COE}$ of the quality of disclosure. These previous studies related the COE to disclosure, but their results were inconsistent and they did not use disclosure as a moderating variable.

\footnotetext{
* Corresponding author: radziah@ukm.edu.my
} 
Moreover, such research sustains the standard setters in developing and initiating other solutions that improve the practice of FV accounting and the quality of information and protect the interests of investors. The lack of literature on the topic relating to risk disclosure, the COE and FV accounting is the second motivation of this research; the aim is to extend the understanding of the effect of moderating risk disclosure on the relationship between FV accounting and the $\mathrm{COE}$ and to clarify the issues pertaining to FV accounting.

Findings from the analysis using generalised method of moments (GMM) support our hypotheses and the discussion in previous studies stating the benefit of practising risk disclosure. To sum up, this study utilized risk disclosure as a tool that could minimize the information asymmetry problem, mitigate risks under FVA and improve risk management, thus reducing the COE.

\section{The Role of Risk Disclosure}

Risk disclosure could contribute to the reduction of future risks arising from asymmetric information. Moreover, the disclosure of information risk is very important, especially after the requirement for FV accounting is mandated and it is especially so for Level 3 type of FVA $(27 ; 28)$. Furthermore, the IFRSs highlight the importance of risk management and disclosure in firms (29) to decrease the asymmetric information problem and thus the COE (30).

The FV measurement involves estimation and thus is expected to result in volatile earnings, errors both intentional and unintentional [(31); (32); (3); (4)]. These issues concerning FV accounting could mislead investors and regulators in making the right investment decision (33) and make raising fund capital difficult, thus increasing the COE (22). So, bank managers who engage in a high level of risk disclosure are expected to disclose more details and information that justify and explain their risks and regain investors' confidence and improve transparency as discussed in Linsley and Shrives (6). Consequently, practising risk disclosure could moderate the relationship between FVA and the COE since it could reduce the information asymmetry in FVA and the probability of the risk premium. Then, the expected rate of return and the COE will also be influenced.

Moreover, theoretical papers by Merton (34), Diamond and Verrecchia (14), Clarkson et al. (15), Healy and Palepu (35), Lambert et al. (36), Bertomeu et al. (37) and Shehata et al (26) indicate the importance of disclosure in determining the COE. Furthermore, Botosan (10), Richardson and Welker (16), Hail (18), Chen et al. (19), Ashbaugh et al. (38), Francis et al. (21; 38), Armitage and Marston (22), Zhaohui (23), Lopes and De Alencar (24) and Lopez (25) empirically reported that disclosure needs to provide more information about the risk and asymmetric information and therefore it can decrease the COE.

However, there are different degrees of information asymmetry and risk associated with each level of FV accounting. The FV accounting estimation models, such as unquoted FVA, have a high level of errors and the estimation of potential unreliability is expected to be high. This is because the management must estimate unquoted assets at FV, which can be subject to discretion or manipulation and many judgements are needed when the model is estimated [(30);(12); (39)]. The error and asymmetric information problem for FV accounting obtained from market prices (quoted FVA) are smaller than those for FV accounting obtained from estimation models (unquoted FVA) (2). Therefore, the cost of raising capital is expected to be high for banks that engage in a high proportion of unquoted FVA; consequently, the need for risk disclosure is greater with unquoted assets at FV than with quoted assets at FV. In this regard, Liao et al. (27) also documented that more disclosure for Level 3 FVA is required by standard setters. The above discussion suggests that the quality and level of risk disclosure differ with the level of FVA; thus, it is expected that the risk disclosure affects the relationship between FVA and the COE differently.

\section{Research Methodology}

\subsection{The research model:}

$$
C O E_{i t}=\alpha_{0}+\beta_{1} \operatorname{COE}_{\mathrm{i}, \mathrm{t}-1}+\beta_{2} \mathrm{FVA}_{\mathrm{i}, \mathrm{t}}+\beta_{3} \mathrm{DIS}_{\mathrm{i}, \mathrm{t}}+\beta_{4} \mathrm{FVA} * \mathrm{DIS}_{\mathrm{i}, \mathrm{t}}+\beta_{5} \text { BETA }_{\mathrm{i}, \mathrm{t}}+\beta_{6} B T M_{\mathrm{i}, \mathrm{t}}+\beta_{7} \operatorname{SIZE}_{\mathrm{i}, \mathrm{t}}+\eta_{\mathrm{i}}+v_{\mathrm{i}, \mathrm{t}}
$$

\section{Variable description:}

DIS $_{\mathrm{i}, \mathrm{t}} \quad$ - disclosure index representing disclosure level of bank $\mathrm{i}$ at time $\mathrm{t}$

The selection included in the index risk disclosure is based on the Basle Committe (1999), IFRS 7 and13, KPMG(2012) and the previous literature [(10); (6); (40)]. For each item of information disclosed, the symbol ' $\sqrt{ }$ ' is given and it will subsequently be awarded 1 mark. However, if the item is not disclosed in the annual report, the symbol ' $\mathrm{X}$ ' is assigned and 0 marks will subsequently be awarded. At the end of the marking process, the total information available in each organization is divided by the total information shoul be reported: index of disclosure which calculated by score earned by bank / maximum score.

$C O E_{i t} \quad$ - dependent variable cost of equity of bank $\mathrm{i}$ at tine $\mathrm{t}$

This is calculated as $\sqrt{\left(E P S_{t+2}-E P S_{t+1}\right) / P i t}$

$\mathrm{FVA}_{\mathrm{i}, \mathrm{t}}$ - the proportion of the total of the asset at FV to total asset of bank $\mathrm{i}$ at time $\mathrm{t}$

$B E T A_{i, t}$ - systematic risk, 
$B T M_{i, t}$ - book to market value

$S I Z E_{i, t}$ - normal logarithm of sum assets.

The error expression $\left(\varepsilon_{i}\right.$ is function of the company particular outcome $\left(\eta_{i}\right)$ and time specific outcome. However, present research based on error term $\varepsilon_{i}=\eta_{i}+v_{i, t}$ and $\eta_{i}$ symbolize error term that is supposed to be founded on unobserved firm particular outcome that lead to hetrogeneity within $C O E_{i, t}$ and $v_{i, t}$ symbolizes reminder stochastic allocations term.

This research employs a dynamic form of the relationship between COE and other explanatory variables as it is expected that the current $\mathrm{COE}$ is influenced by the previous year COE. The coefficients of FVA, BETA and BTM are expected to be positive and significant as these variables are different forms of risk factors. The term FAV*DIS is the testb for the moderating effect.

\subsection{Data and Sampling}

This research extends an earlier research using the same population of listed banks in Asia. Asian market is an ideal setting as the relationship between asymmetric information and COE is more likely in imperfect markets (30) such as those in Asia. Armstrong et al (30) refers to perfect market as when the number of traders is large or infinite and action by any trader is not likely to affect price. This study draws a sample consisting of the largest five Asian (top five in each country) banks for the period 2007 - 2013 because these large banks are the ones holding large assets and resources (especially FVA). the sample starts from 2007 because the FV accounting standards became effective for fiscal year 2008 and early adoption is permitted in 2007 (41). And also in 2007, companies are allowed to practice FV measurement for all financial assets and liabilities as recorded by Fahnestock \& Bostwick (42). The relevant data is extracted from Thomson DataStream and annual reports. Initial data collection yielded an initial sample of 995 bankyear observations. The sample size was subsequently reduced to 509 for a number of reasons. Some financial reports could not be obtained for different reasons such as financial reports were not in the English language and financial reports were unavailable. Some banks are deleted due to missing data required to estimate COE and FVA. The final sample involved 112 banks from 28 countries in Asia.

\section{Research Findings and Discussion}

\subsection{Multivariate Analysis}

The relationship between the variables is based on the result of the dynamic model specifically, GMM, because the GMM model developed by Arellano and Bond (43) was designed for short panel data (44), which is the nature of our sample. Nickell (45) stated that the fixed-effect model estimator is inconsistent for short panel data. The Sargan test shows the model meets the requirement under the hypothesis related to FVA with a p-value of 0.35 in the table below. This indicates that the instruments are valid. Lastly, the research tests the autocorrelation, AR (1) and AR (2). The resulting $p$-values of 0.00 and 0.28 for the tests of AR (1) and AR (2) indicate that the estimates of the dynamic panel with the hypothesis related to FVA do not suffer from first- and second-order serial correlation. As a result, all the assumptions for testing the validity of the dynamic GMM model are met.

\subsection{Discussion}

The table below presents the findings. The second to fourth columns show the results without the disclosure variable. As expected and previously reported FVA and lagged COE are positively and significantly related to COE. More importantly the results of the dynamic model show a negative and significant relationship between the moderating variable FVA*DIS and the COE at the 0.05 level (Table- the last three columns). Thus, the GMM models show that a higher FVA will lower the estimated cost of equity when the level of information about risk disclosure is high. The relationship between the COE and FVA supports the moderating risk disclosure effect because it is positive before adding risk disclosure.

Moreover, the positive and significant relationship between FVA and the COE supports the moderating risk disclosure effect since, it changes to negative when risk disclosure is added. It emphasizes the significance of involving a tool such as risk disclosure that provides information about FVA and thus reduces the COE. This result also indicates that high FVA ratios in banks cause higher risk, which, therefore, lead to a higher COE, since this FV accounting includes a higher level of error and the asymmetric information problem according to the papers by Armitage and Marston (22) and Barth (2).

Consequently, disclosing more information about risk and the way in which banks control it could help to decrease the COE. Further, disclosure is an important factor for reducing the information asymmetry among parties and investors, which is one of the issues involved in FV accounting. This finding is consistent with Linsley and Shrives (6,7); Abraham and Cox (9), Aljifri and Hussainy (8), Amran et al. (5) and Vandemaele et al. (46), who reported that the demand for a high quality of risk disclosure increases when the percentage of risk increases, such as that produced by FVA. 
Because this disclosure makes the project more visible to investors, producing more accurate pictures of firms' economic position and future cash flows, it enhances the stock market liquidity. Consequently, it reduces the rate of return demanded by investors and the COE. The dynamic result indicates that risk disclosure has a strong ability to reduce the COE, which is influenced by FVA.

Table 1: COE, FVA AND RISK DISCLOSURE

\begin{tabular}{|c|c|c|c|c|c|c|c|c|c|}
\hline & \multicolumn{3}{|c|}{ COE with FVA } & \multicolumn{3}{|c|}{ COE with Risk Disclosure } & \multicolumn{3}{|c|}{$\begin{array}{l}\text { COE, FVA and moderating effect } \\
\text { of risk disclosure }\end{array}$} \\
\hline & COEF. & $\begin{array}{l}\text { STD } \\
\text { ERR. }\end{array}$ & P-VALUE & COEF. & STD ERR. & $\begin{array}{l}\text { P- } \\
\text { VALUE }\end{array}$ & COEF. & $\begin{array}{l}\text { STD } \\
\text { ERR. }\end{array}$ & $\begin{array}{l}\text { P- } \\
\text { VALUE }\end{array}$ \\
\hline $\mathrm{COE}_{\mathrm{i}, \mathrm{t}-1}$ & 0.10 & 0.14 & 0.04 & 0.20 & 0.08 & 0.01 & 0.23 & 0.11 & 0.04 \\
\hline FVA & 0.10 & 0.04 & 0.02 & - & - & - & 0.63 & 0.28 & 0.02 \\
\hline BETA & 0.09 & 0.10 & 0.36 & 0.00 & 0.05 & 0.92 & -0.09 & 0.07 & 0.20 \\
\hline BTM & 0.03 & 0.01 & 0.02 & 0.05 & 0.01 & 0.00 & 0.04 & 0.01 & 0.00 \\
\hline SIZE & -0.14 & 0.05 & 0.00 & 0.03 & 0.05 & 0.53 & -0.17 & 0.09 & 0.06 \\
\hline DIS & - & - & - & -0.12 & 0.10 & 0.25 & 0.29 & 0.21 & 0.16 \\
\hline FVA*DIS & - & - & - & - & - & - & -0.85 & 0.44 & 0.05 \\
\hline $\begin{array}{l}\text { Number of } \\
\text { Observations }\end{array}$ & 509 & & & 509 & & & 509 & & \\
\hline $\begin{array}{l}\text { Observations } \\
\text { per Group }\end{array}$ & 115 & & & 115 & & & 115 & & \\
\hline $\mathrm{AR}(1)$ & 0.00 & & & 0.00 & & & 0.00 & & \\
\hline $\mathrm{AR}(2)$ & 0.21 & & & 0.20 & & & 0.28 & & \\
\hline Sargan Test & 0.10 & & & 0.05 & & & 0.35 & & \\
\hline
\end{tabular}

Thus, this result is also consistent with previous research, such as Botosan (10), Richardson and Welker (16), Hail (18), Chen et al. (19), Ashbaugh et al. (37), Francis et al (21,38), Armitage and Marston (22), Zhaohui (23), Lopes and De Alencar (40) Lopez (41). These studies show that high levels of information and disclosure reduce the information asymmetry and improve the coordination between firms and investors, thus decreasing the COE.

Further, this significant and negative result for moderating risk disclosure is consistent with our primary correlation, which shows the importance of risk disclosure in reducing the COE. Moreover, this dynamic model, which includes the moderating risk, is also consistent with hypothesis and the expectations. Therefore, the moderating risk disclosure acts as a buffer and reduces the impact of FVA on the COE.

Moreover, most of the control variables are consistent with the expectations when moderating disclosure is integrated into the model. The BTM is positively and significantly related to the COE at the 0.00 level. Size is another control variable that is significantly and negatively related to the COE at 0.06 level. However, beta is insignificant and not consistent with the expectations. Gebhardt et al. (47) and Hail (18) documented some issues relating to beta that could make it poorly suited to testing the influence of factors on the COE. The lack of significance of the beta is not surprising as it was found by Allee (48).

The table presents an insignificant relationship between disclosure and the cost of equity. This result could also refer to issues of variation between minimum and maximum index disclosure. Thus, the results show a negative and significant relationship between moderating risk disclosure and the COE and indicate that a high level of moderating disclosure affects the relationship between FVA and the COE. And this GMM result is consistent with hypothesis.

\section{Conclusion}

Risk disclosure is believed to be useful for investors' decision making and decreasing the COE. Risk disclosure reports complement the role performed by accounting numbers in FV accounting and produce more accurate pictures of firms' economic position. Accordingly, this research is concerned with the risk disclosure effect on the association between FVA and the COE. Based on the findings of this research, a significant and negative relationship was found between FVA and the COE when risk disclosure moderates. This result suggests generally that a bank with a higher level of FVA will hold a lower level of risk and asymmetric information issues, leading to lowering of the estimated COE when the level of information about risk disclosure is high. The results apply to when FVA is calculated in total or separately as quoted FVA or unquoted FVA.

\section{References}

1. Daske,H. Journal of Business Finance and Accounting, 33(4):329-373.(2006)

2. Barth, M.E. The Accounting Review, 69(1): 1-25 (1994)

3. Lins, K.V., Servaes, H. and Tamayo, A. Financial Management, 40(3):525-551.(2011) 
4. Christensen, H.B. and Nikolaev, V. Review of Accounting Studies, 18(3): 734-775. (2013)

5. Amran, A., Bin, A.M.R. and Hassan, C.H.M. Managerial Auditing Journal, 24(1):39-57 (2009)

6. Linsley, P.M. and Shrives, P.J. Journal of Financial Regulation and Compliance, 13(3):205-214. (2005)

7. Linsley, P.M. and Shrives, P.J. The British Accounting Review, 38(4):387-404. (2006)

8. Aljifri, K. and Hussainey, K., 2007.Managerial Auditing Journal, 22(9):881 -894.

9. Abraham, S. and Cox, P. The British Accounting Review, 39(3):227-248 (2007)

10. Botosan, C. The Accounting Review, 72(3): 323-349. (1997)

11. Ball, R., Robin, A. and Wu, J.S. Journal of Accounting and Economics, 36(1):235-270 (2003)

12. Verdi, R. Financial Reporting Quality and Investment Efficiency. SSRN. (2006)

13. Beyer, A. and Guttman, I. Journal of Accounting Research (2012) 50 (5):1141-1177

14. Diamond, D.W. and Verrecchia, R.E. The Journal of Finance, 46(4):1325-1359. (1991)

15. Clarkson, P., Guedes, J. and Thompson, R. Journal of Financial and Quantitative Analysis, 31(1):69-84. (1996)

16. Richardson, A.J. and Welker, M. Accounting, Organizations and Society, 26(7):597-616. (2001)

17. Botosan, C. and Plumlee, M. Journal of Accounting Research, 40(1):21-40 (2002)

18. Hail, L. European Accounting Review, 11(4):741-773. (2002)

19. Chen, K.CW, Wei, K.C., and Chen, Z. Disclosure, Corporate Governance, and the Cost of Equity Capital: Evidence from Asia's Emerging Markets. SSRN (2003)

20. Cheng, CS A., Denton., and Huang,H. Review of Quantitative Finance and Accounting, 27(2): 175-204. (2006)

21. Francis, J., Khurana, I.K. and Pereira, R. The Accounting Review, 80(4):1125-1162. (2005)

22. Armitage, S. and Marston, C. The British Accounting Review, 40(4):314-336 (2008)

23. Zhaohui, R.X. Journal of Business Research, 3(1):15-26. (2009)

24. Lopes, A.B. and De Alencar, R.C. The International Journal of Accounting, 45(4):443-464. (2010)

25. Lopez Voluntary Disclosure and the Cost of Equity Capital in the Netherlands, Erasmus University, hesis.eur.nl/pub/10248/M818-Lopez_323267.doc. (2011)

26. Shehata, N. F. Accounting and Finance Research, 3(1):18-26. (2014)

27. Liao, L., Kang, H.H.J., Morris, R. and Tang, Q. Information Asymmetry of Fair Value Accounting and Loan Loss Provisions During the Global Financial Crisis. SSRN(2010)

28. Ryan, S.G. Fair Value Accounting: Understanding the Issues Raised by the Credit Crunch. White paper for the Council of Institutional Investors, New York University Stern School of Business. (2008)

29. Taylor, G., Tower, G. and Neilson, J. Accounting and Finance, 50 (2):417-446. (2010)

30. Armstrong, C.S., Core, J.E., Taylor, D.J. and Verrecchia, R.E. Journal of Accounting Research, 49(1):1-40 (2011)

31. Landsman, W.R. Fair Value Accounting for Financial Instruments: Some Implications for Bank Regulation. Workshop on Accounting Risk Management and Prudential Regulation. Basel, Switzerland: Bank of International Settlement. (2006)

32. Laux, C. and Leuz, C. Journal of Economic Perspectives. (2010)

33. Barth, M.E.,Wayne,R., Landsman,B. and James, M.W. Journal of Banking and Finance 19 (3):577-605. 1995

34. Merton, R.C. The Journal of Finance, 42(3):483-510 (1987)

35. Healy, P.M. and Palepu, K.G. Journal of Accounting and Economics, 31(1):405-440. (2001)

36. Lambert, R., Leuz, C. and Verrecchia, R.E.Journal of Accounting Research, 45(2):385-420. (2007)

37. Bertomeu, J., Beyer, A. and Dye, R.A., The Accounting Review, 86(3):857-886 (2011)

38. Ashbaugh, H., Collins, D.W. and LaFond, R. Corporate Governance and the Cost of Equity Capital. Working paper, University of Wisconsin, and University of Low (2004)

39. Ashbaugh, H., Collins, D.W. and LaFond, R. Corporate Governance and the Cost of Equity Capital. Working paper, University of Wisconsin, and University of Low (2004)

40. Sundmacher, M. Consistency of Risk Reporting in Financial Services Firms. SSRN. (2006)

41. Li, F. And Shroff, N. Financial Reporting Quality and Economic Growth. SSRN.(2010)

42. Fahnestock, Robert T. and Bostwick, Eric D. Journal of Finance \& Accountancy, 8, p1. (2011)

43. Arellano, M. and Bond, S. Review of Economic Studies, 58: 277-297 (1991)

44. Roodman, D. How to do xtabond2: An Introduction to Difference and System GMM in Stata. Center for Global Development working paper 103. (2006)

45. Nickell,S. Journal of Econometric Soceity. 1981

46. Vandemaele, Sigrid, Vergauwen, Philip and Michiels, Anneleen, 2009. Management Risk Reporting Practices and their Determinants. University Hasselt.

47. Gebhardt, W.R., Lee, C. and Swaminathan, B., 2001. Toward an Implied Cost of Capital. Journal of Accounting Research, 39(1):135-176.

48. Allee, K.D., 2008. Estimating Cost of Equity Capital with Time-Series Forecasts of Earnings. Working paper, Michigan State University. 